\title{
EXPERIMENTING FOR LONG-TERM TRANSFORMATION. KEY INSIGHTS INTO 20 YEARS OF GERMAN PILOT SCHEMES FOR INNOVATIVE RURAL PUBLIC SERVICE AND INFRASTRUCTURE PROVISION
}

\author{
Alistair Adam Hernández (D), Carolin Schneider \\ Academy for Territorial Development in the Leibniz Association \\ Vahrenwalder Straße 247, 30179 Hannover: Germany \\ adam@arl-net.de•carolin-schneider@freenet.de
}

\begin{abstract}
In a context of highly heterogeneous development prospects for rural areas in the German Federal Republic, maintaining public services and infrastructure in peripheral locations is facing major challenges. Since the 1990s, a number of nationwide and publicly-funded pilot schemes have experimented with innovative approaches for the long-term transformation of the way public services and infrastructure are provided in the countryside. Nevertheless, the continuity of these approaches often turns out to be problematic. This paper analyses a series of pilot schemes as instruments for territorial development and presents new findings at multiple levels for enhancing their performance.
\end{abstract}

Keywords: basic services and infrastructure, demographic decline, Germany, innovation, pilot schemes, rural areas.

\section{Introduction}

The European model of a society based on solidarity is being dramatically put to the test during the COVID-19 pandemic, which has been ongoing since 2020 (Schorn, Franz, Gruber \& Humer, 2021). In particular, but not exclusively, the provision and maintenance of public health services serve here as a meaningful indicator of the capacity of European states to provide for the well-being of their citizens. In harsh times of crisis such as these, the stabilising effect of strong public services and infrastructures seems to be more apparent than before the crisis.

In the German context, the term Daseinsvorsorge is used for all services in the broader sense that the individual needs to lead an adequate life and which are therefore regularly subject to state influence when they are provided in a fundamentally market-based manner (Milstein, 2018). Furthermore, in 1984, the German Federal Constitutional Court stated that Daseinsvorsorge is understood as a public task that 'citizens require of necessity in order to ensure a dignified existence' (GFCC, 1984). This opinion illustrates right away the difficulties in fully grasping the scope of the topic and field of action of public services and infrastructure. 
The often large international and European differences in concepts and understanding of terms only become apparent when analysing the situation in other countries. The German term Daseinsvorsorge usually does not have a detailed equivalent in other European countries (BMVBS, 2013). Even after the development of uniform definitions at EU level around the concept of 'services of general interest' (SGI), in reality the previously coined national terms and established interpretations persist. This is especially true at the local and regional level, where policy and practice are not always familiar with comparatively new EU terminology. A comprehensive analysis of the pan-European as well as of national contexts of SGIs is provided, for example, by Fassmann, Rauhut and da Costa and Humer (2015).

However, these terms and concepts find common ground in the context of European cohesion and regional policy, with the explicit aim of reducing territorial disparities since the Lisbon Treaty came into force in 2008 (Art. 174 TEU). Recent strategic developments in the context of the recently adopted Territorial Agenda 2030 note a continuing need for action in this regard: people and places in Europe are drifting apart as a result of increasing imbalances and inequalities in the areas of 'quality of life' and 'public services', among others (TA2030, 2020). The document specifically recognises the relocation pressures suffered by service providers in rural and peripheral areas and underlines the need for improving their current accessibility, proximity, affordability and quality in order to secure quality of life and prospects for business development.

Focussing on the German Federal Republic through a territorial lens, the very heterogeneous development prospects of rural areas quickly become noticeable. Germany's spatial development is dominated by the contrast between economically and structurally weak regions characterised by outward migration on the one hand, and prosperous regions with strong inward migration on the other. The overlapping nature of societal challenges such as demographic and economic change, the precarious finances of rural local authorities and the globalisation, flexibilisation and digitalisation of services means rural areas face the demanding task of redesigning infrastructures and thus public services to ensure sustainable local services (SRLE, 2018; Tent et al., 2021). In view of the latest forecasts on population development up to 2040, regional disparities in Germany will continue to worsen and in particular peripheral and structurally weak counties and municipalities far away from conurbations will face increasing difficulties in maintaining public services and infrastructures (Maretzke, Hoymann, Schlömer \& Stelzer, 2021).

Having said this, an adequate supply of public services and infrastructures in rural, structurally weak and peripheral regions is a key aspect of their future viability. Awareness of this fundamental role has long existed in Germany among professionals in planning and regional development, among the general public and in the rural population, as well as in politics at all levels. This is why, publicly-funded pilot schemes for the innovative provision and experimental restructuring of rural public services and infrastructures have become an integral part of funding policy at federal and state level since at least the early 2000s. Nevertheless, establishing and mainstreaming experimental approaches in the long-term often turns out to be fraught with difficulties: the necessary structural and organisational changes are often not implemented on a permanent basis and practical projects at ground level fail in the long run. Furthermore, systematised knowledge about barriers, pitfalls and success factors in the process of experimenting and establishing long-term transformations in the area of innovative basic service and infrastructure provision in rural areas are lacking.

Against this background, this research aims to perform a cross-assessment of pilot schemes and funding programmes with an experimental character carried out in Germany in the last two decades with a clear thematic reference to public services and infrastructures in rural areas. A first level of analysis addresses the pilot schemes as steering instruments of territorial development for 
ensuring public services and infrastructures through innovation and testing of new approaches. Research questions raised concerning this perspective are: What effects and interrelations can be found between the development of territorial policy-making affecting rural basic service and infrastructure provision and the analysed pilot schemes? What challenges and chances arise in the process of their implementation? Lastly, how can their design be improved in order to better ensure the long-term sustainability of innovative solutions and therefore to help transform the provision of rural public services and infrastructure in the near future? A second and more applied level of analysis focuses on specific pilot projects taking place under the thematic umbrella of the mentioned schemes. The research interest here lies in more practical questions as for example: What practical obstacles and success factors are associated in general with the implementation of experimental projects in the area of rural public services and infrastructure? What key factors influence the consolidation, long-term establishment and maybe mainstreaming of these innovative projects?

The paper firstly introduces the relevance of public services and infrastructures for fulfilling the socio-political integration and cohesion promised by the German state, especially in rural and structurally week areas. Secondly, it presents and characterises public pilot schemes and funding programmes as steering instruments of territorial development for ensuring public services and infrastructures through innovation and testing of new approaches. After describing the methodologic approach behind the paper, the results chapter sheds light on the mentioned research questions focusing on two main perspectives: pilot schemes as territorial development instruments and practical pilot projects implemented at the heart of these complex funding and planning frameworks. Finally, conclusions are drawn for an improved design of pilot schemes, creating conditions that are more promising for the consolidation of experimental projects and for contributing to the long-term transformation of rural public services and infrastructure.

Thus, this paper contributes mainly to a deeper understanding of the transformational capacity of pilot schemes and funding programmes as territorial development instruments in the overall spatial planning toolbox. Thematic issues in the different areas of rural basic service and infrastructure provision as for example transport, broadband, education or health care stay beyond the scope of analysis.

\section{Public services and socio-spatial (in)equality in rural areas of Germany}

The Federal Republic of Germany is composed of thirteen area and three city federal states (Ger.: Länder). The states are divided into a series of regional and local authorities such as administrative districts (Ger.: Regierungsbezirke), counties (Ger.: Landkreise) and county-free cities (Ger.: Kreisfreie Städte), whereby counties are also subdivided into municipalities (Ger.: Kreisangehörige Gemeinden). This results in a federal and decentralised administration granting especially the states but also the higher levels of local government (e.g. counties) considerable autonomy to develop binding guidelines regarding spatial planning and territorial development.

The guiding concept of social justice has had a territorial dimension since the foundation of the Federal Republic in 1949. In order to ensure citizen participation as well as social and territorial cohesion, the Constitution first enshrined the principle of 'uniformity' and then, as of the constitutional reform of 1994, of 'equivalence of living conditions' (Ger. Constitution art. 72 §2). This 
is a controversial formula in the social sciences, planning and economics, but also in politics and society in the Federal Republic of Germany which has been repeatedly discussed as a political and thus normative guiding principle without a clear or even uniform definition since the 1970s (Rumpf, 2020; Steinführer, Hundt, Küpper, Margarian \& Mehl, 2020). The postulate of 'equivalent living conditions' is also considered one of the most important guiding principles of German spatial development and planning policy (MKRO, 2016).

Historically, the planning philosophy of the Federal Republic of Germany in the post-war decades shaped the defining of this guiding principle as a policy of convergence and evening out of territorial disparities between regions, but also between urban and rural areas. As a result of Germany's post-war 'economic miracle', a higher level of welfare state provision could indeed be achieved in almost all areas of life during this period: at work, in education, consumption, recreation, culture, health, social services, telecommunications, transport and housing. Now, the economic crises of the 1980s and 2000s in particular have shaken the ability of the welfare state to deliver on its central social promise of integration and cohesion and paved the way for the establishment of competitive neoliberal economic policies (Kersten, Neu \& Vogel, 2019).

In the course of the restructuring of local government and increasingly tight municipal budgets, the question of safeguarding important public services and infrastructures in a German federal state that relies strongly on subsidiarity is leading to an ever-greater controversy. On the one hand, the ominous consequences of the long underestimated socio-demographic change for the economic viability of services and infrastructures, but on the other hand, for the political enforceability of appropriate quality standards, especially in rural regions, have steered the political and academic planning debate in a new direction. Against this background, a new interpretation of the goal of equivalence has been called for since the 2000s (Stielike, 2010). In the context of the Federal Republic of Germany, this change in interpretation can be exemplarily observed in the results produced by recurring working groups of spatial scientists and planning practitioners of today's 'ARL - Academy for Territorial Development in the Leibniz Association' since 2006. This change ranges from the emphasis on equal opportunities in participation in professional, economic and social developments, the concentration of infrastructure facilities, the acceptance of a diversity of spatial development patterns and locational competition by actively shaping shrinkage processes (ARL, 2006). It continues towards the criticism of a fixation on municipal equipment standards in the equivalence discourse and the recommendation of an 'outcome instead of input' oriented provision of public services (ARL, 2016) and ends more recently highlighting the imperative upgrading of federal spatial planning and the definition of binding minimum standards for provision of public services (ARL, 2020).

What spatial planners and developers agree on in any case is the existing connection between the constitutionally prescribed principles of the welfare state (Ger. Constitution art. $20 \S 1$ ), the previously explained postulate of the 'equivalence of living conditions' and the existence of adequate public services and infrastructures encompassing the provision of all goods and services needed by citizens. In Germany, the state plays a central role in guaranteeing, financing and legally regulating these services and infrastructures, but private companies and independent organisations, for example in the field of welfare, also provide and manage social and technical infrastructures (Küpper \& Steinführer, 2020). An exemplary overview of the distribution of roles of public, private and independent providers of public services and infrastructure in Germany can be seen in Table 1. 
Table 1. Overview of public, private and third sector providers of public services and infrastructures in the German context

\begin{tabular}{|l|l|}
\hline Area of public services and infrastructures & Type of provider \\
\hline Water management and supply, waste and sewage disposal & Local and regional authorities, private sector \\
\hline Electricity supply & Private sector, local and regional authorities \\
\hline Communication services and technology & Private sector \\
\hline Transport service and infrastructure (public transport) & $\begin{array}{l}\text { Central government, local and regional } \\
\text { authorities, private sector }\end{array}$ \\
\hline $\begin{array}{l}\text { Education (early childhood, schools, vocational education } \\
\text { and training) }\end{array}$ & $\begin{array}{l}\text { Central government, local and regional } \\
\text { authorities, third sector }\end{array}$ \\
\hline Cultural facilities and offerings & Local and regional authorities, third sector \\
\hline Medical and elderly care & $\begin{array}{l}\text { Private sector, local and regional authorities, third } \\
\text { sector }\end{array}$ \\
\hline Local supplies provision & Private sector \\
\hline Emergency services (fire, rescue, etc.) & Local and regional authorities, third sector \\
\hline Housing & Local and regional authorities, private sector \\
\hline
\end{tabular}

Source: own translation based on Küpper and Steinführer (2020).

Past, present and future challenges to the provision of public services in the Federal Republic of Germany are mainly rooted in the megatrend of demographic change (i.a. ARL, 2016; Mattert, Valentukeviciute \& Waßmuth, 2017). In this context, the formula 'fewer - older - more diverse' is often used to describe the ongoing developments (Kösters, 2011). The 'fewer' refers to the decreasing population, the 'older' to the higher average age and the 'more diverse' to the growing number of people with a migrant background. While the first two processes (fewer and older) are important for rural areas, the latter (more diverse) is an important matter for large cities.

Especially in rural but more peripheral regions, the population has been declining for several decades and ageing of the population is an unstoppable trend. Already since the 1970 s, too few children have been born on average and life expectancy has been increasing since the middle of the last century. The fact that many younger people are migrating to jobs and training centres reinforces the described developments throughout the country, especially in structurally weak rural areas. There, older and shrinking population groups increase the pressure on the affordability and functionality of, for example, health and care or fire protection on the one hand due to a greater intensity of use and on the other hand due to a shrinking critical mass, while purchasing power and thus municipal revenues are on the decrease due to younger groups moving away (Krajewski \& Steinführer, 2020). However, this self-reinforcing vicious circle is less pronounced or non-existent in rural regions with strong economies, for example in the areas surrounding growing cities. The diversity of demographic and location-related circumstances is illustrated in Figure 1. Based on the 'Index of Challenges for Basic Service and Infrastructure Provision due to Demographic Change' developed by the Thünen Institut, territories coloured red indicate above average challenges in the Federal Republic of Germany. Blue coloured territories represent challenges below average. The mixed colour patterns resulting from the index's application show that it is not only a fundamental east-west or north-south divide, but actually much more the proximity to the still growing economic centres that determines the logic of less or more pronounced challenges with regard to the safeguarding of public services and infrastructures in rural areas. 


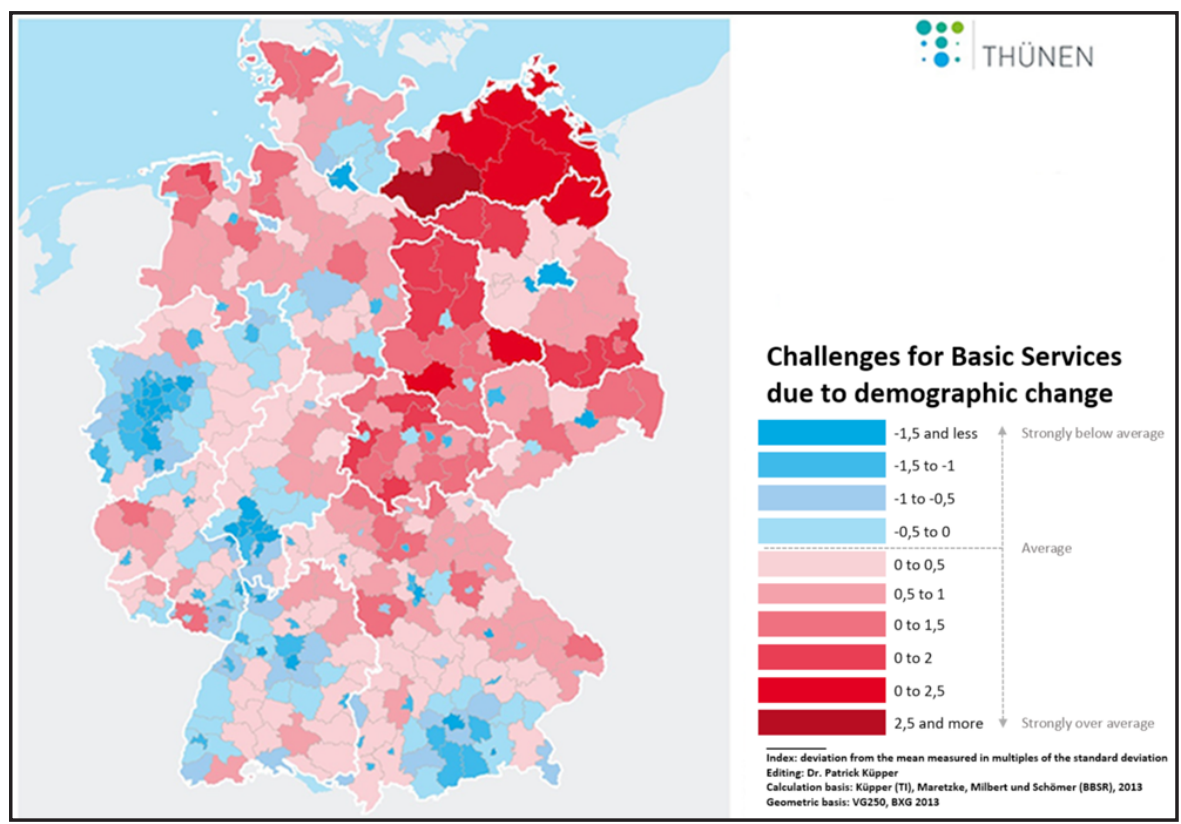

Figure 1. Challenges for basic service and infrastructure provision due to demographic change Source: Küpper (2013).

Finally, the increasing spatial polarisation and social alienation as well as the political resurgence of right-wing populist tendencies in rural regions with a 'strong feeling of being left behind' have noticeably shaped the political and media discourse in the recent years (Deppisch, 2019). Partly in response to this, six working groups of experts from the federal government, the Länder and associations were formed in 2018-2019 to assess the situation with recommendations for action for the remaining legislative period on behalf of three federal ministries under the new name of the 'Commission for Equivalent Living Conditions'. However, what began as an interdisciplinary and interdepartmental joint project of the federal government resulted in separate final reports and caused a lot of resentment, not only among the experts involved but also among a wider expert public, who defend the uttermost importance of the postulate of the 'equivalence of living conditions' for the cohesion and the spatial balance of interests in the Federal Republic (Rumpf, 2020). The main problem is that the plan, titled 'Our Plan for Germany - Equivalent Living Conditions Everywhere' (BMI, BMEL \& BFSFJ, 2019), makes a plethora of recommendations across the various policy areas, but these are not consistently agreed upon within the federal government or even underpinned by specific funding approaches. Thus, this represents a clear expression of the weakness of German cooperative federalism: namely that of agreeing pragmatically on common basic guidelines for nationwide policy (Baumgart \& Priebs, 2019). 


\section{Attributes of the pilot schemes under study as steering instruments of territorial development}

Due to the considerable economic and demographic upheavals in the former GDR, eastern German states and the long economic stagnation at the beginning of the new millennium up to the financial crisis beginning in 2007, various instruments, approaches and strategies for adapting endangered public services in rural areas have been tested in the Federal Republic of Germany since the late 1990s. These instruments for territorial development can be of a planning, infrastructural, financial or legal nature. The publicly-funded pilot schemes analysed throughout this paper represent a mixed form of steering instruments of territorial development and show specific intersections between different types of more traditional instruments for safeguarding public services and infrastructures and their modus operandi (Table 2).

Table 2. Classification of territorial development instrument types for safeguarding public services and infrastructures

\begin{tabular}{|c|c|c|}
\hline Instrument type & Modus operandi & Examples \\
\hline $\begin{array}{l}\text { Legal and binding } \\
\text { instruments }\end{array}$ & $\begin{array}{l}\text { Prohibitions and rules, } \\
\text { instructions }\end{array}$ & $\begin{array}{l}\text { Planning laws, federal and regional planning, } \\
\text { regional planning agreements, binding sectoral } \\
\text { planning, universal services }\end{array}$ \\
\hline Investment measures & $\begin{array}{l}\text { Financial transfers, } \\
\text { construction and operation of } \\
\text { infrastructures }\end{array}$ & $\begin{array}{l}\text { European funding instruments (EAFRD, ERDF, ESF); } \\
\text { common central and federal government tasks; } \\
\text { financial equalisation; funding instruments for } \\
\text { urban development or sectoral programmes; taxes, } \\
\text { levies and fees; participatory budgeting }\end{array}$ \\
\hline $\begin{array}{l}\text { Financial incentive } \\
\text { instruments }\end{array}$ & $\begin{array}{l}\text { Market-based governance, } \\
\text { financial incentives }\end{array}$ & $\begin{array}{l}\text { European funding instruments, urban development } \\
\text { funding instruments for processes and support, } \\
\text { disposition funds at city and regional level }\end{array}$ \\
\hline $\begin{array}{l}\text { Informational- } \\
\text { persuasive } \\
\text { instruments }\end{array}$ & $\begin{array}{l}\text { Inform, convince, form } \\
\text { opinion }\end{array}$ & $\begin{array}{l}\text { Demographic and spatial planning reports, } \\
\text { (information) strategies, scenarios, networked } \\
\text { exchange of information and good practice }\end{array}$ \\
\hline $\begin{array}{l}\text { Management and } \\
\text { process-orientated } \\
\text { instruments }\end{array}$ & $\begin{array}{l}\text { Open and interdisciplinary } \\
\text { process design, informal } \\
\text { planning instruments }\end{array}$ & $\begin{array}{l}\text { Informal sectoral planning, regional development } \\
\text { strategies, participation and cooperation regulations }\end{array}$ \\
\hline Context changes & $\begin{array}{l}\text { Organisational, technical or } \\
\text { governance-related changes } \\
\text { with options of increasing or } \\
\text { reducing effects }\end{array}$ & $\begin{array}{l}\text { Service provision as a result of the interplay of } \\
\text { the state, civil society and the private sector; } \\
\text { voluntary commitment; adaptation and regional } \\
\text { differentiation of standards; dismantling of } \\
\text { settlements; local authority area reforms }\end{array}$ \\
\hline
\end{tabular}

Source: own translation based on ARL (2016).

An important shared characteristic from a spatial planning and territorial development point of view is their legal and financial anchoring at the federal administrative level. A series of federal ministries with manifold sectoral focuses such as housing, building, transport, urban and rural development or agriculture have led and tendered the mentioned pilot schemes throughout the last two decades (see Table 3). Mainly through a competitive selection process, a limited number of rural territories of a regional scope such as counties or other associations of local authorities 
become their protagonists for several years. Their basic principle is to test new solutions and strategic approaches in the area of public services and infrastructure at a regional and local level with the aim of later utilising the resulting findings for nationwide policy-making.

Due to the federal distribution of responsibilities, the federal government may only support these activities in the participating regions to a limited extent in terms of time, subject matter and money, on the pretext of research and development and thus being able to justify additional expense. These experimental fields for territorial development mainly prepare findings for steering spatial planning policy and for the design of so-called long-term 'regular funding' (Ger.: Regelförderung), is otherwise mainly within the jurisdiction of the Länder. In addition, these pilot schemes have been a significant and useful source of solutions and pilot projects with an exemplary and inspiring character for the regions involved or for pilot project promoters and developers elsewhere.

Figure 2 provides a multi-level overview of the complex configuration inherent to the pilot schemes analysed for innovative rural basic service and infrastructure provision. It is important to emphasise their role in experimentation and knowledge creation for policy design, which is rooted in a sometimes challenging feedback loop from the bottom to the top. According to the characteristics of more traditional territorial development instrument types described in Table 2 the mixed design features of the analysed pilot schemes are discussed further below making recurrent references to the numbers (№) embedded in Figure 2.

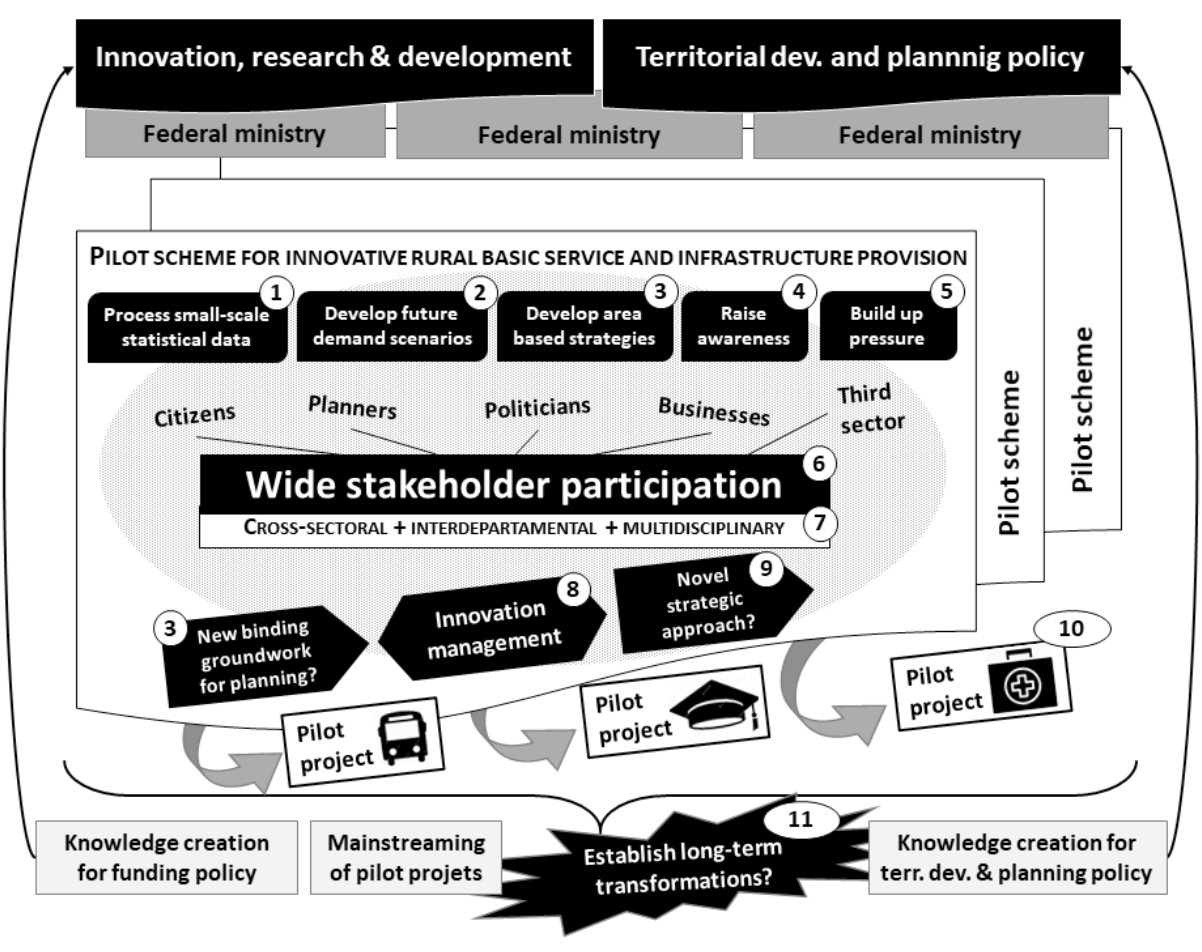

Figure 2. Schematic chart representing the multi-layered and multi-actor nature of the analysed pilot schemes for innovative basic service and infrastructure provision in rural areas of Germany Source: own representation. 
Based on the presented ARL classification, the pilot schemes analysed are discursive processes in the field of informational-persuasive instruments. In general, a new, small-scale data basis (№ 1) for the design of future scenarios and the calculation of demand (№ 2) in the participating regions is developed during the pilot schemes. The concise presentations and the view into the future are used to raise awareness (№ 4) among politicians, infrastructure and service providers as well as the population. In this way, the specific need for action is clarified and the necessary pressure for action is built up (№ 5). These steps for action are typically recorded by an area based strategy document (№ 3), which sometimes serves as a non-binding or soft planning instrument. Discursive processes of this kind are conducted as a network-like cooperation between actors from the state, private sector and civil society inducing wide stakeholder participation (№ 6). The desired interdepartmental, cross-sectoral and interdisciplinary working method (№ 7) is usually coordinated from within a public administration or an intermediary organisation and the stakeholder dialogue and participation process is designed and facilitated usually with external and fully funded professional support.

This brings the process and management-oriented component of the scheme specifications into focus and emphasises the role of external momentum and process advice. Although it is a more voluntary approach, it is usually the task of the commissioned or established management structures - usually regional authorities - to bring about the highest possible commitment of the actors involved by means of formal agreements, project ideas and further cooperation opportunities (№ 8). This external momentum produced by the pilot scheme can at one and the same time be a lever for changing the practices and ways of thinking of the actors involved (№ 9) but also an obstacle to their continuance through their costly incorporation into the traditional structures and working methods in the regional governance model of rural public services and infrastructures.

Finally, the pilot schemes are also an example of financial investment and incentive instruments. In this context, the explicit additional expenditure of the novel strategic approach is largely publicly funded. Public and private co-financing at the regional level of implementation is generally expected. Besides, in pilot schemes, a distinction can usually be made between a conceptual and an implementation phase. The experimental implementation is then carried out through a series of practical pilot projects and initiatives in the different thematic fields of public services and infrastructure (№ 10). Whether and how the changes initiated and the innovative approaches decided upon survive the time after the pilot funding in a stable and productive way is what this paper, inter alia, attempts to clarify (№ 11).

\section{Methods applied}

Methodologically, the findings presented throughout the next chapter of this paper are based on the cross-comparative evaluation of existing accompanying research reports from a series of pilot schemes and funding programmes as well as on seven anonymous, guideline-supported and semi-structured expert interviews. The sampling was guided by focusing exclusively on nationwide pilot schemes with publicly available and independent accompanying research and evaluation Further selection criteria included an innovative and experimental character as well as an exclusive territorial focus on rural areas for their implementation. The pilot schemes and funding programmes have been put out to tender and managed by various federal ministries since the beginning of the 2000s (Tab. 3). Table 3 also summarises relevant information such as their duration, ministerial responsibility, issues covered or official title. 
In order to achieve the goals set, it was possible to draw on various case study evaluations and accompanying research reports analysing the pilot schemes presented, which have been available since 2005. As regards a coherent source critique and document selection, only those reports were analysed that were produced by the authorities and research institutes facilitating and evaluating the programmes and explicitly contained the presentation of field reports and findings from the pilot schemes with an evaluation that contributed to knowledge in this academic field. Thus, documents such as brochures or fact sheets of merely an informative or summarising nature were excluded from the analysis.

Table 3. Summary of pilot schemes and funding programmes analysed in this paper

\begin{tabular}{|c|c|c|c|}
\hline Official title of the pilot scheme & Ministerial responsibility & Duration & Issues and challenges \\
\hline $\begin{array}{l}\text { (MORO) Anpassungsstrategien } \\
\text { für ländliche/periphere } \\
\text { Regionen mit starkem } \\
\text { Bevölkerungsrückgang in den } \\
\text { neuen Ländern }\end{array}$ & $\begin{array}{l}\text { BMVBW }^{1} \text {, } \\
\text { Bundesministerium } \\
\text { für Verkehr, Bau und } \\
\text { Wohnungswesen }\end{array}$ & 2001-2004 & $\begin{array}{l}\text { Demographic decline, social } \\
\text { \& technical infrastructure, } \\
\text { new media, strategic planning }\end{array}$ \\
\hline $\begin{array}{l}\text { (MORO) Innovative Projekte } \\
\text { zur Regionalentwicklung - } \\
\text { Themenfeld „Infrastruktur und } \\
\text { demographischer Wandel” }\end{array}$ & $\begin{array}{l}\text { BMVBS }^{2}, \\
\text { Bundesministerium } \\
\text { für Verkehr, Bau und } \\
\text { Stadtentwicklung }\end{array}$ & $2003 / 2004-2006$ & $\begin{array}{l}\text { Demographic decline, } \\
\text { population aging, settlement } \\
\text { development, land } \\
\text { consumption }\end{array}$ \\
\hline $\begin{array}{l}\text { Regionen Aktiv - Land gestaltet } \\
\text { Zukunft }\end{array}$ & $\begin{array}{l}\mathrm{BMVEL}^{3} \text {, } \\
\text { Bundesministerium } \\
\text { für Verbraucherschutz, } \\
\text { Ernährung und } \\
\text { Landwirtschaft }\end{array}$ & $\begin{array}{l}\text { 2001-2005 } \\
\text { (extension 2007) }\end{array}$ & $\begin{array}{l}\text { Regional value chains, } \\
\text { employment, urban- } \\
\text { rural linkages, renewable } \\
\text { energies, nature \& landscape } \\
\text { conservation }\end{array}$ \\
\hline $\begin{array}{l}\text { (MORO) Regionalplanerische } \\
\text { Handlungsansätze zur } \\
\text { Gewährleistung der öffentlichen } \\
\text { Daseinsvorsorge }\end{array}$ & $\begin{array}{l}\text { BMVBS }^{2}, \\
\text { Bundesministerium } \\
\text { für Verkehr, Bau und } \\
\text { Stadtentwicklung }\end{array}$ & $2005-2007$ & $\begin{array}{l}\text { Regional planning, education, } \\
\text { child \& elderly care, public } \\
\text { transport }\end{array}$ \\
\hline $\begin{array}{l}\text { (MORO) Demografischer Wandel } \\
\text { - Region schafft Zukunft }\end{array}$ & $\begin{array}{l}\text { BMVBS }^{2} \text {, } \\
\text { Bundesministerium } \\
\text { für Verkehr, Bau und } \\
\text { Stadtentwicklung }\end{array}$ & 2007-2011 & $\begin{array}{l}\text { Demographic decline, school } \\
\text { and transport, healthcare, } \\
\text { elderly with disabilities, non- } \\
\text { police hazard prevention, local } \\
\text { supplies, cultural education }\end{array}$ \\
\hline LandZukunft & $\begin{array}{l}\text { BMEL }{ }^{4} \text {, } \\
\text { Bundesministerium } \\
\text { für Ernährung und } \\
\text { Landwirtschaft } \\
\end{array}$ & 2011-2014 & $\begin{array}{l}\text { Regional value chains, social } \\
\text { entrepreneurship \& business } \\
\text { support, innovation funding, } \\
\text { rural tourism }\end{array}$ \\
\hline $\begin{array}{l}\text { (MORO) Aktionsprogramm } \\
\text { Regionale Daseinsvorsorge }\end{array}$ & $\begin{array}{l}\mathrm{BMVI}^{5} \text {, } \\
\text { Bundesministerium für } \\
\text { Verkehr und digitale } \\
\text { Infrastruktur }\end{array}$ & 2011-2015 & $\begin{array}{l}\text { Demographic decline, social } \\
\& \text { technical infrastructure, } \\
\text { strategic planning }\end{array}$ \\
\hline Land(auf)Schwung & $\begin{array}{l}\mathrm{BMEL}^{4} \text {, } \\
\text { Bundesministerium } \\
\text { für Ernährung und } \\
\text { Landwirtschaft }\end{array}$ & $2015-2021$ & $\begin{array}{l}\text { Peripheral rural areas, } \\
\text { innovative strategic planning, } \\
\text { decentralisation and } \\
\text { digitalisation of basic services } \\
\text { \& infrastructure }\end{array}$ \\
\hline
\end{tabular}

Notes: $\mathrm{BMVBW}^{1}$ : Federal Ministry of Transport, Construction and Housing; $\mathrm{BMVBS}^{2}$ : Federal Ministry of Transport, Building and Urban Affairs; BMVEL ${ }^{3}$ : Federal Ministry consumer protection, food and agriculture; $\mathrm{BMEL}^{4}$ : Federal Ministry of Food and Agriculture; BMVI ${ }^{5}$ : Federal Ministry of Transport and Digital Infrastructure

Source: own summary based on the analysed pilot schemes and funding programmes. 
In addition, seven anonymous interviews were conducted with representatives of Federal and Länder ministries, federal authorities and institutes, universities and regional development and facilitation consultancies involved. The interviews were guided, semi-structured and conducted with the main foci previously mentioned: a micro and meso level with a focus on the specific practical or pilot projects emerging within the pilot schemes, and a macro level with a focus on the political design and long-term impact of the pilot schemes themselves. Specific text passages and indirect quotations from the interviews are thus kept anonymous in this paper and only marked numerically (interviewee no 1 is referenced as I 1) and have been translated into English by the author.

The processing of the various sources thus represented an amalgamation of classic document analysis (Glaser, 2013) with structure-building elements from qualitative content analysis (Mayring, 2014; Kuckartz, 2018) and was carried out using MAXQDA qualitative research software. The code system generated revolved around the success factors and implementation barriers at the micro, meso and macro levels as well as around the multifaceted interplay between policy design, pilot schemes, multi-level governance and practical pilot project implementation.

\section{Results from the cross-evaluation of pilot schemes in the field of public services and infrastructures in rural areas}

Hereafter, the evaluation results from the pilot schemes introduced in Table 3 for the experimental reorganisation and adaptation of public services and infrastructures in rural areas in Germany are presented and discussed in an integrated manner. The added value of presenting and discussing results from both empirical sources together - document analysis and interviews - lies mainly in a deeper and more complex understanding of the interrelated range of topics revolving around the design, implementation and impacts of the pilot schemes under study.

\section{Effects of the pilot schemes and funding programmes analysed on policy-making for territorial development and public services and infrastructures in rural areas}

Although the knowledge-creating approach pursued by the pilot schemes seems promising in dealing with the multiple challenges of ensuring public services and infrastructures in rural areas, it encounters a number of structural and issue-specific challenges at the policy-making level. The following results focus on the feedback loop existing between the bottom and top representations of Figure 2.

On the one hand, in the absence of framework-setting regulatory policy and legislation, the pilot schemes that are repeatedly relaunched run the risk of becoming an ineffective policy substitute in the context of federal spatial planning and territorial development (I 4). A good example of this is the still outstanding implementation of specific mechanisms arising from the earlier mentioned strategy paper 'Our Plan for Germany - Equivalent Living Conditions Everywhere' (BMI et al., 2019). This effect is also reinforced in federal legislation due to the lack of transmission mechanisms, such as the building code (Ger.: Baugesetzbuch) in the context of funding programmes for urban development (I 4; I 6; Nischwitz, Chojnowski \& Krönert, 2019). However, the transfer of findings into legislative procedures would be crucial, i.e., in the form of so-called experimentation and opening clauses for testing innovative solutions (Nischwitz et al., 2019).

In addition, the weak involvement of the ministries and authorities of the Länder in the design, implementation and evaluation of the pilot schemes is criticised $(12 ; 13 ; 15 ; 17)$. In some cases, 
this leads to thematic overlaps between uncoordinated federal and state funding programmes $(I 5 ; 17)$, which can rarely be used productively by project promoters and tend to create confusion (I 7). The importance of coordinating funding opportunities and harmonising regulations between the federal government and the Länder for improving the quality of funding policy is an important conclusion drawn from several scientific programme evaluations (Albrecht et al., 2011; Bäumer, Elbe \& Schubert, 2015; Nischwitz et al., 2019; Küpper et al., 2021).

In addition, so-called 'departmental competition' at the federal level alone produces negative effects for a coherent funding policy $(14 ; 15 ; 17)$. The broad range of topics in territorial development and, more specifically, in the policy for ensuring public services and infrastructure in structurally weak rural areas inevitably means that several ministries are affected at the same time, which may adopt an uncoordinated silo-perspective $(15 ; 17)$. From the point of view of the project promoters or potential funding recipients, the lowest co-financing rate or the broadest scope for action for an application for the same project idea can be weighed up among competing pilot schemes (1 4). The latter can create the compulsion to change already mature project ideas to such an extent that, on the one hand, they meet the most favourable financial funding conditions but, on the other hand, their content is so far removed from the original conceptual grounding that the motivation of project promoters and the chances of it becoming consolidated are negatively affected. Furthermore, the so-called 'regional budgets' have proven to be a good instrument in this context at the regional level, which leave the specific orientation of projects predominantly to the decision-makers and project promoters in regional partnerships (Bäumer et al., 2015; Nischwitz et al., 2019; Küpper et al., 2021).

There is a particular need for optimisation in the transfer of tried and tested solutions and project approaches for ensuring the provision of rural public services and infrastructures between federal pilot schemes and eligible regular funding approaches of the common tasks of 'Improvement of the Agricultural Structure and Coastal Protection' (Ger.: Gemeinschaftsaufgabe und Küstenschutz, GAK) and 'Improvement of Regional Economic Structure' (Ger.: Gemeinschaftsaufgabe Verbesserung der regionalen Wirtschaftsstruktur, GRW) at the Federal level $(13 ;|15 ;|$ | $)$. The time-limited nature of the pilot schemes always ensures the short and medium-term development of structures and capacities in the regions, which often have to be abandoned due to a lack of economically viable operating concepts and could use potentially degressive support through regular funding or extended funding to establish themselves in the long term (I 4; I 5). A transparent and systematised transfer of these approaches in mainstream funding guidelines is also called for in recent accompanying research findings (Bäumer et al., 2015; Küpper et al., 2021). However, the strongly investment-oriented character of the regular funding would be difficult to reconcile with the funding of personnel and organisational structures that would provide more dynamisation, initiation of cooperation and promotion of innovation in the less capable and articulate rural regions typically participating in pilot schemes (Küpper et al., 2021).

A final area of tension is the transfer of knowledge in the multi-level system, from the participating regions and their project promoters to the federal ministries via the Länder or state ministries. In this context, static offers such as project databases, implementation guidelines or project reports on paper are not very effective $(|4 ;| 5 ; \mid 7)$. Lessons learnt need more liveliness and person-to-person interaction in order to be better conveyed, for example as thematic or pilot scheme networks with recurring exchange and coordination, outreach advice and know-how transfer as well as interactive online platforms $($ I $5 ;$ I 7$)$. In this way, legislation could be better informed, common mistakes in project development could be avoided and creative ideas could be better disseminated (Küpper et al., 2021). A good example of this is the current creation of a nationwide centre 
of excellence in the field of rural mobility, which will actively involve the existing Länder networks with advice and competence building (I 4).

\section{Findings for optimising the design of pilot schemes and funding programmes in the area of public services in rural areas}

Another essential objective of pilot schemes of the kind discussed here is to provide an external impetus for the participation of actors with previously selected fields of action and for the overall innovative development of public services and infrastructures in a given rural region $(14 ;$ I 6$)$. This is depicted in the core of Figure 2 specifically regarding explaining № 1 to 7 . However, the energy with which a region takes up the impetus gained in the pilot scheme can vary enormously. In the best case, the content of the pilot scheme and suitable preparatory activities in the respective region come together. Two ways of bringing about this 'matching' seem to be common in the context of the examined funding programmes: an upstream selective competition of regions on the basis of their thematic development strategies or a continuous qualification process of projects as a preliminary examination and prerequisite for access to funding.

Competitions increase the political enforceability of the selection of winning regions, e.g., by shifting the decision-making to an external jury, and can, with adequate funding for professional process facilitation and design (I 6), generate a positive surge of participation within its boundaries. However, published evaluation research shows that such upstream competitions neither increase significantly the motivation of regional stakeholders nor ensure the selection of the best strategies in terms of content (Bäumer et al., 2015; Küpper et al., 2021). Unintended side effects are an increase in the pressure to implement if the application is successful $(12 ; 16)$ and the generation of frustration and participation fatigue in the opposite case (Bäumer et al., 2015; Kundolf, Küpper, Margarian \& Wandinger, 2016; Küpper et al., 2021). In order to 'keep regional actors in line', small but quick projects and successes are needed on the one hand (I 2), while on the other hand budgets set on a an annual basis and the limited time frame of the pilot schemes create pressure from the programme side for a quick outflow of funds (Bäumer et al., 2015; Kundolf et al., 2016; Küpper et al., 2021).

Continuous qualification and advisory support for emerging projects within the pilot schemes and funding programmes are more promising. The novelty of the approaches tested and the coordination of diverse groups of actors in the participating multi-actor networks require different amounts of time until the final application is ready; a factor of great importance for their long-term sustainability and continuity $(15 ; \mid 6)$. Thus, it could be argued that openness in the application maturation process and professional support and consultancy ensure a good match of regional needs with the appropriate funding - possibly even outside the pilot scheme in question - in a proactive sense.

A relevant but also controversial design feature of pilot schemes is the project promoters' own contribution (co-funding) and its proportion relative to the total amount of approved funds. There is a consensus that a higher contribution on the part of the promoter increases the commitment towards the measure to be implemented $(14 ; 16 ; 17)$, but this should be graded differently depending on the type of executing body (e.g., municipality, district administration, non-profit association or profit-oriented company). Nevertheless, financial bottlenecks in rural local and regional authorities and a limited critical mass of service recipients or customers are the reason why the safeguarding of services and infrastructures is addressed in the context of model specifications in the first place. Recognising the value of unpaid working hours carried out by volunteers, and making it easier to combine further funding or a graduation according to the socio-economic situation of subsidy recipients might be ways to reduce these hurdles (Kundolf et al., 2016). 
Finally, the pilot schemes under consideration are associated with high transaction costs in terms of their technical processing. Not only are the lengthy coordination processes between the stakeholders involved criticised, but so are the submission, approval and amendment of funding applications, state aid audits, deadlines and other financial management requirements (Nischwitz et al., 2019; Küpper et al., 2021). This areas complexity seems to be so great that the accompanying research of the pilot scheme 'Land(auf)Schwung' has already proposed it as a specific topic for a separate future pilot scheme (Küpper et al., 2021).

When reflecting on all the design features described in the nationwide pilot schemes and funding programmes, interviewees have clearly expressed the fact that professionalisation, i.e., outstanding skills at procuring funding, grants the regions and their key actors a decisive competitive advantage $(|4 ;| 5 ; \mid 6)$. This highlights the issue of particularly articulate and capable regions that, despite socio-spatial disadvantages, are generally more successful in calls for proposals than their peers. These regions are increasingly able to organise themselves to follow the rhythm of the socalled "funding cycle in which a specific menu is offered by the 'funding economy" (Kundolf et al., 2016 , p. 293) and tend to disregard independent development based on endogenous potentials and needs. To mitigate this effect, structural indicators of socio-spatial development are sometimes set as limiting criteria in the calls for proposals of funding programmes $(\mid 3 ;$ | 4 ; I 5). In addition, existing accompanying research shows that the focus on disadvantaged areas has so far not had any significant negative effects on the commitment of funds despite inherently unfavourable conditions (Bäumer et al., 2015; Küpper et al., 2021).

\section{Obstacles to the implementation of specific practical projects within the pilot schemes}

As a broad field of action for pilot schemes, the provision of public services and infrastructures is perceived by participating regional partnerships and actors in practice as multi-layered, considerably demanding and notably complex (Kocks, Thrun, Winkler-Kühlken \& Hübler, 2005; Gatzweiler et al., 2006; Elbe et al., 2007; Albrecht et al., 2011; Kundolf et al., 2016; Nischwitz et al., 2019; Küpper et al., 2021).

In the first so-called 'Pilot Schemes in Regional Planning' (Ger.: Modellvorhaben der Raumordnung - MORO) within the thematic framework of public services and infrastructures (until 2007), the compilation of a useful data base with small-scale statistics (e.g., for precise demographic forecasts) and realistic future scenarios (e.g., resulting in future needs analysis of rural population) as a so-called 'Regional Strategy for Public Services and Infrastructures' (Ger.: Regionalstrategie Daseinsvorsorge) proved to be a true challenge (see explaining № 1 to 5 in Fig. 2). Nevertheless, preparing these regional strategies has generally succeeded in reducing complexity, raising awareness of sometimes gloomy future scenarios and pointing out options for effective action $(|1 ;| 2)$. In the context of wide stakeholder participation, the complexity of the topics placed high demands on the wider expert public and often overwhelmed interested citizens (I 2).

Aspects such as public procurement law or legal regulations and minimum standards of public services and infrastructures are usually at the centre of criticism $(11 ; 12 ; 15)$. However, the findings in the accompanying research analysed are not clear in this regard. Pilot projects seem to be less inhibited by the existence of regulations and standards than by their design which rarely invited innovation (Gatzweiler et al., 2006; Dehne, Kaether \& Neubauer, 2016). Rather, this challenge stems from the resource-intensive technical clarification required to test a novel approach or the basic assumptions of existing legislation that presupposes population growth instead of actual decline (Kocks et al., 2005; Gatzweiler et al., 2006; Dehne et al., 2016). 
Furthermore, the scarcity of public budgets is a constant, which prevents pilot schemes from succeeding in establishing transformations in the long-term. Due to the territorial focus on rural and structurally weak regions, temporary funding can only partially eliminate the budget-problem $(|1 ;| 2 ; \mid 6)$. There seems to be a lack of balance in the effort put into the upstream preparatory or strategy-generating phase and the later implementing phase (Elbe et al., 2007; Gutsche et al., 2009; Dehne et al., 2016). In the evaluation of the pilot scheme 'Modellvorhaben der Raumordnung (MORO) - Aktionsprogramm Regionale Daseinsvorsorge', this assessment by the participating regions was clearly revealed: demands were made for more funds and more time for the implementation of practical pilot projects (Nischwitz et al., 2019).

A constant companion of the design of rural services and infrastructures is also the discussion about adequate financing of tasks that legally fall to local and regional administrations $(|2 ;| 3 ; \mid 4)$, whereby it can be stated that no funding programmes can compensate for their chronic underfunding in rural areas (I 7). The call for a revision and redefinition of the funding basis for these areas is also a recurring theme in the accompanying research analysed (Kocks et al., 2005; Gatzweiler et al., 2006; Elbe et al., 2007; Küpper et al., 2021).

The final evaluation report of the most recent pilot scheme titled 'Land(auf)schwung' makes the following instructive reference to the contradiction between scarcity of financial resources and the intended strengthening of innovative capacity in rural regions by means of the funding programmes: '[...] necessity is not the mother of invention, but rather of risk aversion, as the responsible actors do not want to waste scarce resources on failed innovations' (Küpper et al., 2021, p. 111). Furthermore, the report states that radical innovations - and thus projects with a true innovative character - require free capacities, a long-standing build-up of expertise and knowledge, and the possibility that projects can fail and be revised (Küpper et al., 2021). This is difficult to reconcile with the time-limited and scarce nature of funding programmes.

The interviewees also bring up the issues of 'willingness to innovate and experiment' (see explaining № 8 in Fig. 2) several times together with the basic attitudes and abilities of the main addressees in the pilot schemes, namely the public administrations and their planning departments. A lack of capacity to cooperate and innovate is repeatedly criticised in this regard $(1)$; । 2 ; I 5 ; । 7). Persistent sectoral organisation within the civil service structures - 'fear of thresholds with regard to one's own departmental responsibility' (Nischwitz et al., 2019, p. 68) - as well as a lack of interdisciplinary and collaborative culture clearly stand in the way of the intended integrated and innovative approach (see explaining № 7 in Fig. 2). Finally, the bureaucratic and lengthy processing of funding hinders the participation of innovative partners from the private sector and civil society (I 2; I 5; Küpper et al., 2021).

A final bottleneck for restructuring and innovation in rural public services and infrastructures is the role of local politics. From the approval of funds for co-financing, to the strategic orientation of public efforts, to the cross-cutting restructuring of organisational units in the public administration, the willingness and acceptance or proactive engagement of local politicians is crucial $(11 ;|2 ;| 4)$. The complexity and the highly-charged 'loser debate' around the issue of services and infrastructures in structurally weak regions (Nischwitz et al., 2019), as well as the difficulty of outranking the competition on the hustings with effective results from the pilot schemes in the next election campaign ( 2 ; I 4 ) work against this acceptance. 


\section{Success factors in the implementation of specific pilot and practical projects within the pilot schemes}

The establishment of a broad, diverse and functioning regional partnership was a prerequisite of all the pilot schemes analysed here (see explaining № 6 in Fig. 2). Cooperation was characterised by inter-municipal or inter-institutional measures and projects (Kocks et al., 2005) and its success is strongly related to fruitful collaboration within partnerships. In the framework of working and steering groups, cooperation should be open-ended as well as interdisciplinary and interdepartmental $(|1 ;| 2 ; \mid 4)$. In addition, the inclusion of social and business partners from outside the usual administrative framework is relevant $(1 ; ; 6)$. The latter in particular should be involved as early as possible in the planning and design of innovative approaches, as they are often worthy of consideration as possible long-term sponsors and promoters of the emerging projects and measures (I 7).

For this new cooperation 'in a flatter organisational logic' to be successful, aspects of professional process facilitation and communication are considered to be highly important (I 6). Building trust is an important and time-consuming prerequisite for getting new actors to collaborate (I 1; I 2 ; । 5). Key personalities of recognised prestige from business, civil society and politics can do a sensitising, inspiring and convincing job as advocates $(|1 ;| 2)$. However, the dialogue process needs skilful facilitation and steering; after all, it involves politically sensitive issues and decisions which are embedded in the competitive relations of regional and local politics (Gatzweiler et al., 2006; Gutsche et al., 2009; Dehne et al., 2016; Nischwitz et al., 2019). Therefore, preparing the contents and processes in a user-friendly manner, as well as regular reporting in the regional media, serves to make pilot schemes and their results transparent and legitimate to the public (Elbe et al., 2007; Albrecht et al., 2011; Dehne et al., 2016; Nischwitz et al., 2019).

In order to launch successful practical pilot projects on the innovative design of rural public services and infrastructures during the pilot schemes (see explaining № 10 in Fig. 2), the role of the organisational and innovation management structures set up and the staff working in them is crucial. In the first place, they ensure that the principles of multidisciplinary, interdepartmental and cross-sectoral cooperation are integrated in project development $(1,12 ; \mid 6)$. By actively managing the network involved, they can bring partners together and explore cooperation opportunities for initiating pilot and practical projects, as well as acting as advisors and facilitators during their development (Dehne et al., 2016; Kundolf et al., 2016; Nischwitz et al., 2019). Thus, they have an important linking function and dovetail the efforts of administrative, business and social partners among each other, as well as with politics in the pilot schemes (Nischwitz et al., 2019). As already mentioned in the previous chapter, it is very important when starting and stabilising the projects that these management structures are continued and financed after the initial funding ends (I 1; I 2; I 3) or are institutionalised in a public or semi-public structure (Nischwitz et al., 2019).

Aid organisations and infrastructure providers as well as certain civil society organisations are particularly close to the actual needs in the various areas of public services. Activating them, in a leading role at the start of a practical project in the pilot schemes analysed turned out to be a relevant success factor (Bäumer et al., 2015; Kundolf et al., 2016; Nischwitz et al., 2019; Küpper et al., 2021). This is achieved by allowing these target groups to set their own topics and embedding appropriate financial incentives within the pilot schemes (Bäumer et al., 2015; Dehne et al., 2016; Nischwitz et al., 2019). However, the limits of volunteering have also become clear over the years: the complexity and duration of funding procedures $(11 ; 16)$, the limited capacity for implementation on the part of volunteer project promoters $(13 ;|4 ;| 5)$ and the predominant desire to create new offers and additional qualities instead of safeguarding existing areas of public services at risk (Küpper et al., 2021) represent visible obstacles for their successful involvement. 


\section{Long-term establishment and consolidation of pilot and practical projects within the pilot schemes}

Implanting newly-established organisational structures such as regional innovation management units (see explaining № 8 in Fig. 2) including their own staff with a clear cross-sectional and interdepartmental approach, is of crucial importance for the continuation or also institutionalisation of the transformations initiated by the pilot schemes - especially in the case of public actors in the regions (Dehne et al., 2016; Nischwitz et al., 2019). Either by reassigning existing personnel or taking on new, a beefed up workforce represents a form of maintaining the momentum after the pilot schemes, which play a decisive role in further initiating, qualifying and consolidating practical pilot projects (Dehne et al., 2016; Nischwitz et al., 2019).

The likelihood of this continuation increases on the one hand with a good match between regional efforts on the ground and the momentum provided by the pilot schemes, but on the other hand is made more difficult by the municipalities' usual lack of financial muscle and already limited staff. The fact that the regions have to come up with new or rethought fields of action and approaches - i.e., the demand to act in a more innovative and regionally cooperative way - is part of the pilot scheme framework conditions, but at the same time too foreign and incomprehensible to local government and politics that their efforts run the risk of not being included in their core tasks once the scheme funding runs out $(12 ; 14)$. As shown by the experiences in the last pilot scheme 'Modellvorhaben der Raumordnung (MORO) - Aktionsprogramm Regionale Daseinsvorsorge', the regional innovation management units should continue to be funded by the programme during a potential project implementation phase and not be abruptly discontinued before that point (Nischwitz et al., 2019).

Another relevant aspect is that of engaging early on with establishing the long-term organisational structures, personnel and projects that were initially funded in the pilot schemes; something that is increasingly required by the funding programmes' tender documents $(1)$; I 2 ; $13 ;$ I 4$)$. This process requires specific key people - often from the political or management and coordination field (I 2) - at the implementation level who recognise the added value of activities that will probably come to an end after the pilot scheme runs out. They typically start negotiating to keep the projects going in strategic dialogue with relevant partners at an early stage and carry them through with tenacity to a successful conclusion (। 2; | 4).

Often, early consideration of the framework conditions for the long-term sustainability of the projects and initiatives launched leads to the realisation that an innovative or alternative support structure or corporate form needs to be established among the stakeholders. These changes in regulatory structures within and outside organisations are referred to as 'institutional learning' in the final evaluation of the pilot scheme 'LandZukunft' and describe how the informal or formal rules of regional governance in a specific area of provision of public services are further developed and adapted through organisational innovations (Kundolf et al., 2016). In this regard, some interviewees would like to see more forcefulness on the part of the local and regional authorities to initiate such processes of change and restructuring. In addition, they would encourage them to take a stronger lead in innovative and cooperative organisational structures with additional partners from the private and third sector to provide services in an innovative way $(|1 ;| 2 ; \mid 6)$.

Finally, the linchpin for the sustainability of projects and initiatives of public services and infrastructures is their long-term economic viability. So projects that develop a professional business and financing model and roll it out during or after the initial funding has expired are more likely to be successful $(12 ;|3 ;| 6)$. This requires a certain willingness to take risks on the part of the partners $(|1 ;| 2)$ and, as explained in previous chapters, a bold attitude like this can often fall short 
in structurally weak rural regions. If sufficient income is also lacking, sponsoring models or longerterm institutional funding from the participating local or regional authorities also come into play for their consolidation $(11 ; 12 ; \mid 5)$. Earmarking funding and other regulations with regard to funded project investments have an inhibiting effect here and can frustrate their success $(15 ; \mid 6 ; 17)$. Finally, projects that actively seek or conceptually integrate a basic level of utilisation of the services offered or infrastructures provided in their development phase seem to have better prospects for long-term sustainability (I 1).

\section{Conclusions}

In view of existing economic and demographic forecasts, socio-spatial polarisation in the Federal Republic of Germany will continue to increase in the coming decades. This is associated with well-researched challenges for the safeguarding of rural public services and infrastructure. This paper highlights the importance of a nationwide political will throughout Germany's differentiated multi-level administrative and planning system to implement the necessary reforms and transformations in the various areas of public services and infrastructure. The results presented show that a change from an obstructive and uncoordinated federalism to one that is cooperative and interlocking will be of utmost importance for the sustainability of public services and infrastructures in rural areas, especially those with declining populations.

The pilot schemes analysed here demonstrate the well-researched nature of innovative solution testing and the gathering of valuable expertise for the implementation of this necessary change. Nevertheless, their transformational capacity could be considerably increased subject to a series of improvements presented throughout the previous chapters. Firstly, there is a clear need for optimising the transfer of findings into federal and state legislation as well as adapting approaches to the new orientation of regional funding policy. Legal and, above all, organisational and financial framework conditions urgently need to be adapted in order to give the innovative approaches, painstakingly developed and tested in the pilot schemes, adequate and realistic prospects for long-term success. Also, a further shift in emphasis in the funding strategy behind the schemes from the public sector to the third and private sectors, as well as relaxing the limits on the subjects of study and on the trial period until results are clear, could increase the capacity to connect between the ideas of funders and the needs of beneficiaries. A more determined focus on specific collaborative and innovative projects in the everyday practice of rural public services and infrastructures instead of mere strategy and planning documents could make the necessary changes more tangible and communicable for service recipients and those politically responsible in local and regional authorities. Finally, more intensive, longer accompaniment and capacity-building for project promoters seems promising. Access to funding (e.g., investment, running costs for staff and additional external consultancy expertise) should be coupled with demonstrable and professional engagement with the long-term organisational and financial viability of the innovative solution to be tested. The abrupt loss of funding or advisory support or even the systemic dependence on subsequent funding should be firmly prevented by the design of pilot schemes.

Lastly, the current diversity of important tasks, actors, responsibilities and levels of action for a functioning provision of public services and infrastructures between the state, the market and the voluntary sector should be pointed out one last time. Achieving the goal of 'equivalent living conditions', especially in disadvantaged rural areas, requires all the more the coordinated cooperation of stakeholders involved. Civil society and the third sector should not be included as the 
last resort in the event of state and market failure, but included from the outset as fundamental partners for establishing an inherently need driven provision of public services and infrastructures in rural environments. It will continue to be the task of the state to facilitate the spaces for experimentation while at the same time steering and supporting multi-level planning and multi-actor networks.

\section{Acknowledgments}

This contribution is anchored in the InDaLE project, which runs from 2020 to 2022 and is supported by funds of the Federal Ministry of Food and Agriculture (BMEL) based on a decision of the Parliament of the Federal Republic of Germany via the Federal Office for Agriculture and Food (BLE) under the Rural Development Programme.

\section{References}

Albrecht, M., Dehne, P., Dosch, A., Glatthaar, M., Gutsche, J.-M., \& Kaether, J. (2011). Regionalstrategie Daseinsvorsorge - Denkanstöße für die Praxis (Demographischer Wandel - Region Schafft Zukunft). Federal Ministry of Transport, Building and Urban Affairs \& German Federal Institute for Building, Urban Affairs and Spatial Development. Retrieved from https://www.demografie-portal.de/DE/ Service/Publikationen/_altes-Format/Downloads/Regionalstrategie-Daseinsvorsorge_2011. pdf?_blob=publicationFile\&v=1

ARL (2006). Gleichwertige Lebensverhältnisse: Eine wichtige gesellschaftspolitische Aufgabe neu interpretieren! Position Paper, 69. Academy for Territorial Development in the Leibniz Association. Retrieved from https://shop.arl-net.de/gleichwertige-lebensverhaltnisse-eine-wichtige-gesellschaftspolitische-aufgabe-neu-interpretieren.html

ARL (2016). Daseinsvorsorge und gleichwertige Lebensverhältnisse neu denken. Perspektiven und Handlungsfelder. Position Paper, 108. Academy for Territorial Development in the Leibniz Association. Retrieved from https://shop.arl-net.de/daseinsvorsorg-und-gleichwertige-lebensverhaeltnisse-neu-denken.html

ARL (2020). Raumordnung. Anwalt für gleichwertige Lebensverhältnisse und regionale Entwicklung. Eine Positionsbestimmung. Position Paper, 115. Academy for Territorial Development in the Leibniz Association. Retrieved from https://www.arl-net.de/de/blog/neu-erschienen-positionspapier-115-raumordnung-anwalt-f\%C3\%BCr-gleichwertige-lebensverh\%C3\%A4ltnisse-und

Bäumer, K., Elbe, S., \& Schubert, D. (2015). Geschäftsstelle LandZukunft - Abschlussbericht und Auswertung der Abschlussberichte 2014 der Modellregionen "Landzukunft". Federal Ministry of Food and Agriculture. Retrieved from https://www.bmel.de/SharedDocs/Downloads/Landwirtschaft/LaendlicheRaeume/LandZukunft/ModellvorhabenLandZukunft-AbschlussberichtGeschaeftsstelle.pdf

Baumgart, S., \& Priebs, A. (2019). Unser Plan für Deutschland - Gleichwertige Lebensverhältnisse Überall. Nachrichten der ARL, 49(02). Retrieved from https://shop.arl-net.de/media/direct/pdf/nachrichten/2019-2/nachrichten-2019-2.pdf

BMI, BMEL \& BFSFJ (2019). Unser Plan für Deutschland- Gleichwertige Lebensverhältnisse überall Schlussfolgerungen von Bundesminister Horst Seehofer als Vorsitzendem sowie Bundesministerin Julia Klöckner und Bundesministerin Dr. Franziska Giffey als Co-Vorsitzenden zur Arbeit der Kommission "Gleichwertige Lebensverhältnisse". German Federal Ministry of the Interior, Building and Community, Federal Ministry of Food and Agriculture \& Federal Ministry for Family Affairs, Senior Citizens, Women and Youth. Retrieved from https://www.bmfsfj.de/resource/blob/137240/ e94cf2ffab8768fd37a1e632db3ee51e/schlussfolgerungen-kommission-gleichwertige-lebensverhaeltnisse-langversion-data.pdf 
BMVBS (2013). Daseinsvorsorge im europäischen Vergleich - Problemwahrnehmung, Lösungsstrategien, Maßnahmen. Federal Ministry of Transport, Building and Urban Affairs. Retrieved from https:// www.bbsr.bund.de/BBSR/DE/veroeffentlichungen/ministerien/bmvbs/bmvbs-online/2013/DL_ ON042013.pdf?__blob=publicationFile\& $v=2$

Dehne, P., Kaether, J., \& Neubauer, A. (2016). Aktionsprogramm regionale Daseinsvorsorge. Abschlussbericht Projektassistenz. Federal Ministry of Transport and Digital Infrastructure. Retrieved from https://www.bbsr.bund.de/BBSR/DE/veroeffentlichungen/ministerien/bmvi/bmvi-online/2016/ bmvi-online-03-16-dl.pdf?__blob=publicationFile\&v=3

Deppisch, L. (2019). 'Wo sich Menschen auf dem Land abgehängt fühlen, hat der Populismus freie Bahn' - Eine Analyse des populär-medialen Diskurses zu der Bedeutung von Infrastrukturverfall, Abstiegsangst und rechten (extremistischen) Werten für den Zuspruch zum Rechtspopulismus. Working Paper, 119. Johann Heinrich von Thünen Institute, Federal Research Institute for Rural Areas. https://doi.org/10.3220/WP1550668971000

Elbe, S., Kroes, G., Benz, A., Lukesch, R., Weiß, K., Böcher, M., Krott, M., Meincke, A., Middelmann, U., Payer, H., Rabenau, J., \& Tränkner, S. (2007). Begleitforschung 'Regionen Aktiv': Synthesebericht und Handlungsempfehlungen. Göttingen: Universitätsverlag Göttingen. https://doi.org/10.17875/ gup2007-260

Fassmann, H., Rauhut, D., da Costa, E. M., \& Humer, A. (Eds.). (2015). Services of general interest and territorial cohesion: European perspectives and national insights. Vienna: Vienna University Press, V\&R Unipress.

Gatzweiler, H.-P., Bergmann, E., Einig, K., Jakubowski, P., Kocks, M., Spangenberg, M., Mensching, K., Fischer, T., \& Kretzer, A. (2006). Umbau statt Zuwachs - Siedlungsentwicklung und öffentliche Daseinsvorsorge im Zeichen des demographischen Wandels - Innovative Projekte zur Regionalentwicklung. The Federal Office for Building and Regional Planning \& Federal Ministry of Transport, Building and Urban Affairs.

GFCC (1984). Sentence as of 20th March 1984, Az. 1 BvL 28/82, Guideline = BVerfGE, 66, 248, 258. Enteignung für Zwecke der öffentlichen Energieversorgung zugunsten privatrechtlich organisierter Energieversorgungsunternehmen. German Federal Constitutional Court. Retrieved from https:// www.bundesverfassungsgericht.de/DE/Entscheidungen/Liste/60ff/liste_node.html

Glaser, E. (2013). Dokumentenanalyse und Quellenkritik. In B., Friebertshäuser, A., Langer, A., Prengel, H., Boller \& S., Richter (Eds.). Handbuch qualitative Forschungsmethoden in der Erziehungswissenschaft (4. Edition, pp. 365-375). Weinheim: Beltz Juventa.

Gutsche, J.-M., Rümenapp, J., Schiller, G., Fahrenkrug, K., Melzer, M., \& Einig, K. (2009). Regionalplanerische Handlungsansätze zur Gewährleistung der öffentlichen Daseinsvorsorge (Begleitforschung). Federal Ministry of Transport, Building and Urban Affairs \& German Federal Institute for Building, Urban Affairs and Spatial Development. Retrieved from https://www.bbsr.bund.de/BBSR/DE/ veroeffentlichungen/bbsr-online/2009/ON322009.html

Kersten, J., Neu, C., \& Vogel, B. (2019). Gleichwertige Lebensverhältnisse - für eine Politik des Zusammenhalts. Politik und Zeitgeschichte, 46, 4-11.

Kocks, M., Thrun, T., Winkler-Kühlken, B., \& Hübler, K.-H. (2005). Anpassungsstrategien für ländliche, periphere Regionen mit starkem Bevölkerungsrückgang in den neuen Ländern. The Federal Office for Building and Regional Planning. Retrieved from https://www.bbsr.bund.de/BBSR/DE/veroeffentlichungen/ministerien/bmvbs/wp/1998_2006/2005_Heft38.html

Kösters, W. (2011). Weniger, bunter, älter: Den demografischen Wandel aktiv gestalten (2nd ed.). Munich: Olzog.

Krajewski, C., \& Steinführer, A. (2020). Daseinsvorsorge in ländlichen Räumen und ihre Ausgestaltung zwischen Staat, Markt und Ehrenamt. In C., Krajewski \& C.-C., Wiegandt (Eds.). Land in Sicht: Ländliche Räume in Deutschland zwischen Prosperität und Peripherisierung (pp. 242-260). Bonn: Bundeszentrale für Politische Bildung.

Kuckartz, U. (2018). Qualitative Inhaltsanalyse: Methoden, Praxis, Computerunterstützung (4. Ed). Weinheim: Beltz Juventa. 
Kundolf, S., Küpper, P., Margarian, A., \& Wandinger, C. (2016). Koordination, Lernen und Innovation zur Entwicklung peripherer ländlicher Regionen - Phase II der Begleitforschung zum Modellvorhaben LandZukunft. Johann Heinrich von Thünen Institute, Federal Research Institute for Rural Areas. Retrieved from https://www.bmel.de/SharedDocs/Downloads/DE/Broschueren/ModellvorhabenLandZukunft-BegleitforschungTI-Final.html

Küpper, P. (2013). Herausforderungen bei der Daseinsvorsorge durch den demographischen Wandel. [Map] Johann Heinrich von Thünen Institute, Federal Research Institute for Rural Areas. Retrieved from https:// www.thuenen.de/de/thema/laendliche-lebens-shyverhaeltnisse/daseinsvorsorge-zwischen-abbau-umbau-und-aufbau/demographischer-wandel-wer-ist-betroffen/

Küpper, P., \& Steinführer, A. (2020). Daseinsvorsorge in ländlichen Räumen. Informationen Zur Politischen Bildung, 343, 16-25.

Küpper, P., Brensing, J., Bergholz, C., Mettenberger, T., Pollermann, K., \& Tuitjer, G. (2021). Ländliche Regionen entwickeln: Erkenntnisse der Begleitforschung zum Modellvorhaben Land(auf)Schwung für die Praxis. Johann Heinrich von Thünen Institute, Federal Research Institute for Rural Areas. Retrieved from https://literatur.thuenen.de/digbib_extern/dn063341.pdf

Maretzke, S., Hoymann, J., Schlömer, C., \& Stelzer, A. (2021). Raumordnungsprognose 2040. German Federal Institute for Building, Urban Affairs and Spatial Development. Retrieved from https://www. bbsr.bund.de/BBSR/DE/veroeffentlichungen/analysen-kompakt/2021/ak-03-2021-dl.pdf? blob=publicationFile $\& v=4$

Mattert, J., Valentukeviciute, L., \& Waßmuth, C. (2017). Gemeinwohl als Zukunftsaufgabe: Öffentliche Infrastrukturen zwischen Daseinsvorsorge und Finanzmärkten. Heinrich-Böll-Stiftung \& Gemeingut in BürgerInnenhand (GiB). Retrieved from https://www.boell.de/de/2017/06/22/gemeinwohl-zukunftsaufgabe-oeffentliche-infrastrukturen-daseinsvorsorge-finanzmaerkte

Mayring, P. (2014). Qualitative content analysis: Theoretical foundation, basic procedures and software solution. Klagenfurt. Retrieved from https://nbn-resolving.org/urn:nbn:de:0168-ssoar-395173

Milstein, A. (2018). Daseinsvorsorge. In Handwörterbuch der Stadt- und Raumentwicklung (pp. 361373). Academy for Territorial Development in the Leibniz Association.

MKRO (2016). Leitbilder und Handlungsstrategien für die Raumentwicklung in Deutschland. Conference of Ministers for Spatial Planning. Retrieved from https://www.bmi.bund.de/DE/themen/heimat-integration/raumordnung-raumentwicklung/grundlagen/leitbilder/leitbilder.html

Nischwitz, G., Chojnowski, P., \& Krönert, W. (2019). Verstetigung des Aktionsprogramms regionale Daseinsvorsorge (ArD) in 21 Modellregionen - Studie im Rahmen des MORO 'Netzwerk Daseinsvorsor$g e^{\prime}$. German Federal Ministry of the Interior, Building and Community. Retrieved from http://www. regionale-daseinsvorsorge.de/fileadmin/files/Netzwerk_DV/PDF/MORO_3_Forschung_Verstetigungsstudie_barrierefrei.pdf

Rumpf, J. (2020). Gleichwertigkeit der Lebensverhältnisse - Editorial. Ländlicher Raum, 03(20), 1.

Schorn, M., Franz, Y., Gruber, E., \& Humer, A. (2021). The COVID-19 pandemic: Impetus for placeand people-based infrastructure planning. Town Planning Review, 92(3), 329-334. https://doi. org/10.3828/tpr.2020.83

SRLE (2018). Erwartungen an die Arbeit der Kommission "Gleichwertige Lebensverhältnisse" und zu notwendigen Vorab-Maßnahmen zugunsten ländlicher Räume. Council of Experts on Rural Development, Federal Ministry of Food and Agriculture. Retrieved from https://www.bmel.de/SharedDocs/Downloads/DE/_Ministerium/Beiraete/srle/Stellungnahme-SRLE-2018-04-30.pdf;jsessionid=7A5AC2F44812693EE9FE1C57CODE9955.live852? _blob=publicationFile\&v=3

Steinführer, A., Hundt, C., Küpper, P., Margarian, A., \& Mehl, P. (2020). Gleichwertigkeit der Lebensverhältnisse - wissenschaftliche Verständnisse und Zugänge. Ländlicher Raum, 03(20), 12-17.

Stielike, J. M. (2010). Wieviel Gleichheit erfordert Gleichwertigkeit? - Folgerungen einer Neuinterpretation des Gleichwertigkeitsziels für die Daseinsvorsorge. In C., Hannemann, H., Glasauer, J., Pohlan, A., Pott, \& V., Kirchberg (Eds.). Jahrbuch StadtRegion 2009/2010 Stadtkultur und Kreativität (1st ed.). Opladen: Verlag Barbara Budrich. https://doi.org/10.2307/j.ctvdfOftq 
TA2030 (2020). Territorial Agenda 2030 - A future for all Places. German Federal Ministry of the Interior, Building and Community \& German Federal Institute for Building, Urban Affairs and Spatial Development. Retrieved from https://www.territorialagenda.eu/files/agenda_theme/agenda_data/ Territorial\%20Agenda\%20documents/TerritorialAgenda2030_201201.pdf

Tent, N., Brad, A., Klöden, J., Adam Hernández, A., Bannert, J. \& Gebauer, A. (2021). A review of the challenges and strategies of delivering services of general interest in European rural areas. Europa XXI, 41, 77-105. https://doi.org/10.7163/Eu21.2021.41.4 